\title{
The Influence of Actual and Ideal Self-Congruity on Consumers' Purchase Intentions
}

\author{
Jenasha Tooray, Devina Oodith \\ University of KwaZulu-Natal (Westville Campus), Durban, South Africa \\ oodithd@ukzn.ac.za
}

\begin{abstract}
During the course of consumer behaviour research an augmented focus pertaining to consumer brand selection and the reason/s why consumers purchase a particular brand became evident. Research postulates that consumers tend to purchase brands that have personality attributes that closely correspond to their actual self-concept and enhance their self-image, thereby bringing them closer to their ideal selfconcept. Self-congruity is of paramount importance to marketing for the reason that most of the products consumers purchase are influenced by the images consumers have about themselves. According to Sirgy in 1982, self-congruity defines the procedure in which consumers match their own self-concept with the imageries of a particular brand (as cited in Sohn \& Yuan, 2011). In this era of hyper competition in the marketplace, it is imperative that marketers establish and preserve an enduring, mutually beneficial relationship between their brands and their target markets in order for their companies' growth and survival. This article aims to assess the influence that actual and ideal self-congruity have on consumers' purchase intentions with reference to the clothing and mobile phone brands that are purchased by consumers. This study was undertaken in EThekwini (Durban), South Africa and was conducted within a Public Tertiary Institution comprising of postgraduate and undergraduate students from three colleges. The institution comprised of thirteen Schools which participated in this study. A sample of 385 respondents was drawn using simple random sampling with a $100 \%$ response rate from respondents. Since students represent a lucrative market segment for marketing managers to penetrate, a survey was undertaken in order to unearth whether there exists a congruous relationship between the self-concept of students and the personality attributes of the brands they purchase; and to determine the impact that this relationship has regarding students' brand preference, customer-brand satisfaction and brand loyalty on students' purchase intentions. Data for the sample was collected using a self-developed, precoded questionnaire whose psychometric properties were statistically determined. Data was analyzed using descriptive and inferential statistics. The results indicate that actual and ideal self-congruity does influence purchase intentions significantly and there exists a positive relationship among students' actual and ideal self-congruity, brand preference, customer-brand satisfaction and brand loyalty. Consumers tend to base brand choices for clothing and mobile phones very closely to their perceptions of their actual and ideal self-concepts thus this becomes important for marketers to monitor and target in order to better influence future purchase intentions of these consumers. Based on the results of the study recommendations have been made to better understand consumers and their actual and ideal selves more critically with a view to servicing them more efficiently. The results, thus enable marketing managers to improve brand loyalty, brand preference and customer-brand satisfaction among consumers; and gain insight into consumers' actual and ideal self-congruity.
\end{abstract}

Keywords: Self-congruity, actual-self congruity, ideal-self congruity, self-concept, customer brand satisfaction, brand preference and brand loyalty

\section{Introduction}

A plethora of research advocates that consumers elect to purchase brands that are analogous to their own self-concepts in order to express themselves, for example, an individual can express that he/she is strong and tough by driving a strong and tough vehicle, like a Hummer or a Jeep. Aaker (1997) asserts that products' nonfunctional attributes could influence the consumers' decision to purchase. Today consumers have a basal requirement to obtain social approval and consequently attempt to attain positive impressions of themselves in the minds of others (Zinkhan, Haytko \& Ward, 1996). The focal point of this study is to reconnoitre the relationship between consumers' actual and ideal self-concepts together with their congruent relationship with brand personality. In addition, the study seeks to unearth the actual and ideal self-congruity of consumers and the impact that these elements have on customer-brand satisfaction, brand preference and brand loyalty. Self-concept is of paramount importance to marketing for the reason that most of the products consumers purchase are influenced by the images consumers have about themselves. Not much is known about whether the actual/real self has greater influence on brand preferences compared to the ideal self. On 
similar parameters, it is therefore imperative for marketing managers to understand the impact that the actual self and ideal selves have on consumers' purchase decisions, brand preference, brand loyalty and customer-brand satisfaction. One of the most lucrative market segments in South Africa is university or tertiary institution students. Although there is a vast number of college students who are unemployed and their income comes mainly from tertiary institution loans and parental contribution, students represent an extremely substantial and significant market segment for a myriad of products like mobile phones, clothing, shoes and even automobiles (Eder, 2013; Mokhlis \& Salleh, 2009). Today's youth are virtually change agents whereby they influence the general public and social conventions (Leslie, Sparling \& Owen, 2001).

During this current epoch of globalization, youth represent an important and lucrative market segment for brands, therefore, for the purpose of this study; the population of relevance will be the university youth. Most of the young adult population in South Africa is highly brand conscious as reiterated in a study conducted by the University of Cape Town, Unilever Institute of Strategic Marketing, in conjunction with Youthdynamix (Yutar, 2005). From a marketing standpoint, tertiary institution students have been recognized as a unique target market that constitutes a dominant consumer spending group (Grant \& Waite, 2003). Clothing, mobile phones and entertainment are large expenses for this group. The young adult population more specifically the females, execute a significant role in the market place. This is due to the fact that young female consumers exercise great influence over the distribution of purchasing power through a cumulative number of product groups namely clothing, handbags and shoes (Hogg, Bruce \& Hill, 1998). It's imperative to note that young female consumers have become increasingly affianced in the process of fashion consumption as compared to their male counterparts and the older consumer market. Today there has been an emerging trend of students becoming more and more brand conscious, with most students having a desire to show off to others. A survey conducted by on college students recently, and based on that survey brand names play a significant role when consumers decide what to purchase. In addition, when it came to making decisions about their purchases, price and "getting a good deal" were the topmost explanations. From the plethora of research which indicates that University students are a lucrative market for marketers to tap into, the cardinal point of the research is to ascertain whether students purchase clothing and mobile phones with images or brand personality attributes that correlate to their self-concept. Moreover, the challenge will be to determine the extent to which the congruence between self-concept and brand personality attributes lead to consumer-brand satisfaction, brand loyalty and brand preference.

Consumers evaluate brands based on their self-concept and what they aspire to be. Research posits that consumers purchase brands that have imageries or personality attributes that match their own self-concept. Brand personality, which signifies human characteristics associated with a brand (Aaker, 1997), is an imperative component of the image for brands such as Samsung (innovative), Estee Lauder and Chanel (classy), and Marlboro (rugged). Consumers view brand personality as a way to express their actual or ideal self (Keller \& Richey, 2006). Furthermore, research postulates that the image of the consumer affects the brand's image evaluation ergo consumers choose brands that are congruent with their own self-concept and enhance their self-concept. Although there is a plethora of studies that hypothesize the connection between self-concept and brand personality which influences brand preferences, very few have explored the actual and ideal-self and their relationship in influencing consumers' purchase intentions and brand choices.

\section{Self-congruity}

A myriad of researchers have illustrated the significance of self-concept in consumer behaviour and the congruence with a consumer's self-concept and the image or personality of a particular brand. This relationship plays a vital role in brand loyalty, customer-brand satisfaction, brand preference and choice. Therefore, researchers posit that self-congruity signifies consumers purchasing brands that they associate with a set of personality attributes that match their own (Abel \& Buff, 2010). According to Graeff (1996: 6) "the greater the similarity between a consumer's self-image and the brand's image, the more favorable their evaluations will be for that brand". The self-congruity theory developed by Sirgy in 1982 is a conceptual framework which explains the myriad of processes associated with the self, namely the evaluation and perception of the self, self-concept change, differentiation and generalization, decision-making, information search and self-monitoring. Furthermore, self-congruity influences brand preference, purchase intentions, brand choice and brand loyalty (Ericksen, 1996). Moreover, in 1982, Sirgy (as cited in Boksberger, Dolnicar, 
Laesser \& Randle, 2011) postulated that self-congruity signifies the degree of similarity between a consumer's perception of themselves and the perception of a brand. Ekinci \& Riley (2003) indicate that the self-congruity notion suggests that when the congruence between consumers' self-concept and the personality or image of a brand is strong, the greater the probability of intention to purchase.

Pioneer studies of consumer behaviour research conducted over the decades portray that self-congruity affects customer-brand satisfaction, brand preference, purchase intentions, and brand choice (Parker, 2005). Sirgy \& Su (2000) suggest that consumers prefer brands with an image that is congruent with their own selfconcept, meaning that individuals prefer certain brands because they see themselves as being similar to the types of people that are typically believed to use this brand. In 1982, Sirgy established four types of selfcongruity where each of the self-concepts relates to the consumer's perception of brands (as cited in Boksberger et al., 2011). They are actual self-congruity (the actual or real image of an individual), ideal selfcongruity (the desired image of an individual or how an individual would like to be), social self-congruity (the image of how one is seen by others), and ideal social self-congruity (the image of how one would like to be seen by others). Out of these four congruent relationships, actual self-congruity and ideal self-congruity have the greatest effect on consumption behaviour.

Moreover, self-congruity is defined as the match between a brand's image or personality and an individual's self-concept, namely their actual self, ideal self, social self or ideal social self (Sirgy \& Su, 2000). Self-congruity epitomizes the degree of similarity between a consumer's self-image and the brand's image. In addition, consumers purchase brands that possess personality traits which are similar to their own (Randle \& Dolnicar, 2009). Researchers have indicated that consumers select brands that are believed to be congruent with their self-concept and in addition, according to Malhotra, in 1981, this similarity influences brand preference (as cited in van de Rijdt, 2008). Consequently, a deduction can be made that consumers' purchase preferences are influenced by the images that consumers have of themselves. Self-congruity is viewed as a psychological process in which the consumer focuses on the brand user image and compares this image to his/her selfconcept (Sirgy \& Johar, 1999). Sirgy, in 1982, stated that consumers will hold a more positive attitude towards the brand when there is a strong congruence between the brand's image and consumer's selfconcept (as cited in Sirgy \& Johar, 1999). Preceding research indicates that consumers' product preferences and their purchase intentions can be influenced by self-congruity (Ericksen, 1996). Research suggests that self-image congruity has a strong influence on consumers' brand preferences and their purchase intentions (Ericksen, 1996; Mehta, 1999). Moreover, in her study, Ericksen (1996) discovered an association between self-congruity and consumers' intention to purchase certain motor vehicle brands. Self-congruity therefore enables positive behaviour and attitudes toward brands (Ericksen, 1996; Sirgy \& Johar, 1999).

Actual Self-congruity: Sirgy \& Johar (1999) describe self-congruity as the correlation between the brand's image or personality and consumers' self-image or how they perceive themselves. Actual self-congruence signifies the degree of match between a customer's actual self-image and a brand's image or personality (Sirgy \& Su, 2000). Actual self-congruity means that consumers purchase brands with images or personalities that are consistent with how they see themselves.

Ideal self-congruity: An ideal self-image incorporates attributes one aspires to have (Sirgy \& Johar, 1999). Sirgy \& Su (2000) indicate that ideal self-congruence is the degree of similarity between customers' ideal selfimage and a brand's image or personality. Researchers have proposed that the acquisition and consumption of products that are consumed publicly are influenced more by consumers' ideal self-congruence rather than their actual self-congruence. Additionally, the acquisition and consumption of products that are consumed privately by consumers are more affected by consumers' actual self-congruence rather than their ideal selfcongruence (Abel \& Buff, 2010; Hong \& Zinkhan, 1995). On the same token, a study conducted by Graeff (1996), who examined the connection between the image of a brand with consumers' actual self-image and ideal self-image and the evaluation of the brands consumed publicly and privately, revealed that consumers' evaluations of the brands consumed publicly were influenced more by the similarity between the brand's image and the consumer's ideal self-image as compared to actual self-image. This study will predominately focus on the actual and ideal self-concepts and will examine the actual and ideal self-congruity of consumers and the impact that they have on consumers' purchase intentions. 
Self-congruity's impact on brand loyalty, customer-brand satisfaction, brand preference and choice: Schiffman \& Kanuk (2000) advocate that consumers purchase and consume brands with personality attributes that closely match their own self-images. In addition Aaker (1999) states that consumers express their identity by electing brands with personalities that match their own personalities. Today, brand personality is an attractive and appealing concept in the field of marketing, which has warranted such an overwhelming focus over recent years. Brand personality symbolically has been considered as an instrument that facilitates consumer self-expression (Aaker, 1997; Escalas \& Bettman, 2005; Johar, Sengupta \& Aaker, 2005). Jamal \& Goode (2001) revealed that self-congruity is a strong predictor of satisfaction and Park \& Lee (2005) posit that there exists a positive influence of congruence between the brand's personality attributes and consumers' self-concept, pertaining to a consumer's satisfaction towards the selected brand, their brand preference and brand loyalty. A myriad of research has established the fact that, when congruency is high between brand personality and consumers' self-concept, this tends to have a more favourable effect on brand preferences, brand loyalty, brand attitudes, evaluation of brands, purchase intentions and customer-brand satisfaction. Ergo, the more consumers' purchase brands with personalities that are congruent with themselves the more satisfied and loyal they will be to that particular brand, since it expresses who they are and how they would like to see themselves in the future. According to Kim, Han \& Park (2001), the more consumers can express their self-concepts through identifying with a brand, the more likely they are to consistently use the brand and become loyal to that particular brand. Consumer researchers state that the stronger the congruence between consumers' self-concept and a brand's image the greater the influence on consumers' brand preference, purchase intention and brand loyalty (Sirgy, Lee, Johar \& Tidwell, 2008).

In his research, Mehta, explored that brand preference can be influenced by consumers' self-image or selfexpression, which in turn affects consumers' purchase intentions (Mehta, 1999). It can be deduced that there exists a positive relationship between consumers' self-congruity and brand preference and when there is a strong correlation between consumers' actual and ideal self-congruity, the greater the degree of brand preference. In addition, according to Han (2006), when consumers' actual and ideal self-concepts are congruent with the attributes of a brand, the greater the degree of brand preference as consumers view the brand as a tool to express or enhance their self-concept. Research postulates that when consumers perceive brand personalities to be parallel to their own self-concept, their satisfaction level increases and in addition, consumers are fond of using brands as vehicles to express who they are to society (Kim, Lee \& Ulgado, 2005). Kotler (2000) states that when consumers are satisfied with a brand, this tends to have a positive effect on brand loyalty. Ergo, when consumers perceive that the brand's personality is congruent with their own selfconcept, their satisfaction level towards that particular brand increases, which has a positive effect on the quality of the consumer-brand relationship that develops. The impetus of the study is to unearth whether there exists a congruous relationship between the self-concept of students and the brands of clothing and mobile phones they purchase. Furthermore, the underlying motivation is to determine the impact that this relationship has on students customer-brand satisfaction, brand preference and brand loyalty regarding students' purchase intentions. Therefore, this study will examine the actual and ideal self-congruity of consumers and the impact that these elements have on consumers' purchase intentions.

Aim of the Study: For the purpose of this study, the descriptive research design was employed, in order to reconnoitre the existing information about the phenomena under investigation and describe the congruous relationship that exists between them. This research design was utilized in order to determine whether consumers purchase brands of clothing and mobile phones with personalities that correspond with their actual and ideal self-concepts.

\section{Methodology}

Respondents: The population consisted of all the undergraduate and postgraduate students from a Public tertiary institution in EThekwini (Durban), South Africa. The simple random sampling technique was applied in order to make generalizations of the population as a whole. Using Sekaran's (2003) population-to-sample size table, a corresponding minimum sample of 372 respondents was required however 385 responses were received (over a 100 percent response rate). The adequacy of the sample was determined using the KaiserMeyer-Olkin Measure of Sampling Adequacy (0.901) and the Bartlet's Test of Spherecity (8683.752, p = 0.000 ) which respectively indicated suitability and significance. The results indicate that the normality and 
homoscedasticity preconditions are satisfied. In terms of the composition of the sample according to the findings, the 18-23 year age group comprised of 70.9\%, followed by $24-29$ years (20.5\%), the over 36 year olds constituted (4.4\%) and finally the 30-35 years (4.2\%). The majority of respondents were in the 4th year / Honours year of study (29.6\%), followed by the 3rd year students (26.2\%), 1st year students comprised $(15.8 \%)$ of the sample, 2 nd year students (14.0\%), Masters Students (9.6\%) and PhD candidates (4.7\%). The female respondents (64.9\%) constituted a larger percentage in comparison to the male respondents (35.1\%). The majority of respondents comprised of Africans (50.6\%), followed by Indians (37.1\%), followed by Whites (7.8\%), Coloureds (3.4\%) and 1.0 percent was from another unspecified race group. In terms of Employment status it was reported that Full-time students comprised of 76.4 percent of the population, followed by the unemployed (11.2\%), the employed were reported at (9.1\%) and part-time students made up the remaining part of the sample (3.4\%). In terms of Living arrangements the Majority of the respondents live with parents (55.6\%), followed by those that live in student accommodation (26.8\%), those living with $1+$ individuals comprised of $(10.6 \%)$ and those living alone (7.0\%). Finally on terms of Income most of the respondents (37.4\%) earned <R1 000, 15.3\% earned between R1 001-R3 000, 8.6\% earned >R9 000, 7.5\% earned between R3 001-R6 000, 3.1\% earned between R6 001-R9 000 and 28.1\% of the respondents did not wish to disclose their income.

Measuring Instrument: Data was collected using a self-developed, pre-coded, electronic questionnaire consisting of three sections. Section A dealt purely with the biographical data (age, year of study, gender, race, employment, living arrangements \& income). Section B tapped into Student's perceptions of Actual SelfCongruity. Whilst Section C tapped Student's perceptions of Ideal Self-Congruity. Section A was nominally scaled with precoded option categories, Sections B \& C required respondents to rate each item using the Likert Scale ranging from strongly disagree (1) to strongly agree (5). The questionnaire was framed on the basis of identifying recurring themes that surfaced while conducting the literature review. These confirmed face and content validity. Furthermore, in-house pretesting was implemented to evaluate the suitability of the instrument. Pilot testing was also carried out on twenty students to test the appropriateness of questions and their understanding thereof. No inadequacies were identified and the final questionnaire was considered appropriate in terms of relevance and construction.

Research Procedure: The research was only conducted after a gatekeeper's permission letter was received; ethical clearance was granted and after the pilot test was conducted.

Measures/Statistical Analysis of the Questionnaire: The validity of the questionnaire was assessed using Factor Analysis. A principal component analysis was used to extract initial factors using SPSS with a Rotated component matrix. In terms of validity 6 items load significantly on Factor 2 and account for $10.89 \%$ of the total variance. Of the 6 items, three items relate to actual self-congruity and three items pertain to ideal selfcongruity. Since ideal self-congruity has the highest item loading - 0.751, Factor 2 can be labelled likewise. Furthermore it was noted that 7 items loaded significantly on Factor 3 and accounted for $9.42 \%$ of the total variance. Of the 7 items, three items pertained to actual self-congruity; three items pertained to ideal selfcongruity and 1 item related to customer-brand satisfaction. Since actual self-congruity had the highest loading - 0.628, Factor 3 was labelled as actual self-congruity. The items were also reflected as having a very high level of internal consistency and reliability with Cronbach's Coefficient Alpha being 0.834 with item reliabilities ranging from 0.799 to 0.856 .

Administration of the Measuring Instrument: This study was undertaken in EThekwini (Durban), South Africa and was conducted within a Public Tertiary Institution comprising of postgraduate and undergraduate students from three colleges. The institution comprised of thirteen Schools which participated in this study. The online questionnaire method was utilized, which was created by employing Google Forms. A personalized message was e-mailed to respondents inviting/asking them to respond to the online survey by clicking on the link included at the end of the e-mail. Informed consent was captured by prompting respondents to click on a radio box once they had understood the terms and conditions highlighted in an attached informed consent document. Those who agreed continued with participation. Those who did not wish to participate in the survey, were prompted to withdraw from the survey and terminate their participation, without any negative consequence. Section A dealt purely with the biographical data (age, year of study, gender, race, employment, living arrangements \& income). Section B tapped into Student's 
perceptions of Actual Self-Congruity. Whilst Section C tapped Student's perceptions of Ideal Self-Congruity. Respondents had to answer all sections in the questionnaire.

Statistical Analysis of the Data: Descriptive statistics (mean, variance, standard deviation) and inferential statistics (correlation, t-test, ANOVA and multiple regression) were used to evaluate the objectives and hypotheses for the questionnaire.

\section{Results}

The Influence of Actual and Ideal Self-congruity on Consumers' Purchase Intentions: Consumers' perceptions of actual and ideal self-congruity were evaluated using the five-point Likert scale and the higher the mean score value the more satisfied the respondents were in terms of purchase intentions.

Table 1: Descriptive Statistics: The Influence of Actual and Ideal Self-congruity on Consumers' Purchase Intentions

\begin{tabular}{llllllll}
\hline & \multicolumn{3}{c}{ Statistic } & & & & \\
Dimension & N & Mean & Median & Std. Dev. & Minimum & Maximum & Range \\
\hline Actual Self-congruity & 385 & 2.74 & 2.82 & 0.669 & 1 & 5 & 4 \\
Ideal Self-congruity & 385 & 2.81 & 2.90 & 0.739 & 1.00 & 4.70 & 3.70 \\
\hline
\end{tabular}

Table 1 depicts the dimensions of actual and ideal self-congruity that impact on consumers' purchase intentions in varying degrees. In descending level of impact the mean scores are as follows:

- Ideal self-congruity (Mean $=2.81)$

- Actual self-congruity (Mean $=2.74)$

It is evident that the mean scores were low. There is room for improvement. In order to assess the areas for improvement for both dimensions, the following can be noted. With reference to the respondents' perceptions of the dimension of actual self-congruity pertaining to mobile phones, the results indicated that $45.2 \%$ of the respondents strongly disagree/disagree that they do not care about the type of mobile phone brand that is purchased as it does not reflect who they are and $39.4 \%$ of the respondents agreed/strongly agreed. Pertaining to the clothing brands purchased, $46.5 \%$ of the respondents strongly disagree/disagree that they do not care about the clothing brands they purchase as it does not reflect who they are, whereas $35.6 \%$ agreed/strongly agreed. In terms of the respondents' perceptions of the dimension of ideal selfcongruity, pertaining to mobile phones, it was revealed that $42.1 \%$ of respondents strongly disagree/disagree that they do not care about the type of mobile phone brand that is purchased as it does not reflect how they would like to be, while $34.6 \%$ of respondents agreed/strongly agreed. With reference to the clothing brand/s purchased, the results indicate that $42.6 \%$ of respondents strongly disagree/disagree that they do not care about the type of clothing brand/s that is purchased as it does not reflect how they would like to be, whereas $37.2 \%$ of respondents indicated that they agreed/strongly agreed. Hence, it can be deduced that the majority of the respondents care about the types of clothing and mobile phone brands that are purchased as these brands reflect both their actual and ideal self-concepts. However, the minor variation in responses indicate that respondents prefer to purchase mobile phones and clothing that express who they are (actual selfconcept) rather than how they would like to be (ideal self-concept). Upon close reflection of the findings, it was deduced that the respondents' purchase intentions are influenced more by their actual rather than their ideal self-concept.

Actual and Ideal Self-congruity: Most/Least Important Brand Personality Attributes: This section will present the findings that pertain to the most and least important brand personality attribute relating to the respondents' actual and ideal self-concepts with reference to the clothing and mobile phone brands they purchase. The first segment will elucidate the most and least important brand personality attribute pertaining to the respondents' actual self-concept with reference to the clothing and mobile phones they purchase and the subsequent segment will feature the most and least important brand personality attribute pertaining to the respondents' ideal self-concept regarding the clothing and mobile phone brands they purchase. 
Actual self-congruity: mobile phones - most/least important brand personality attributes: The results indicate that $40.5 \%$ of the respondents believe that the innovative and up-to-date attributes are important for mobile phones to possess as this is congruent with their actual self-concept. Additionally, $39.6 \%$ of respondents believe that it is not important for mobile phones to be innovative and up-to-date. From the findings, $20.8 \%$ of respondents believe that the inexpensive and thrifty attributes are important vis-à-vis mobile phones as this is congruent with their actual self-concept. However, $50.9 \%$ of respondents believe that it is not important for mobile phones to be inexpensive and it is immaterial for them to be frugal or thrifty consumers as this attribute is incongruent with their actual self-concept. Hence, it can be deduced that the brand personality attribute that is of importance pertaining to mobile phones is innovative and up-to-date, as this is congruent with the respondents' actual self-concept. On the contrary, the brand personality attribute that is of the least importance to the respondents is inexpensive and thrifty, as this is incongruent with respondents' actual self-concept.

Actual self-congruity: clothing - most/least important brand personality attributes: As depicted in the results, $57.4 \%$ of respondents indicated that the adventurous and outdoorsy attributes are unimportant for clothing brands to possess as it does not reflect who they are, whereas $17.7 \%$ of the respondents believe that clothing brands should reflect the adventurous and outdoorsy personality attributes as this is congruent with their actual self-concept. From the results, $43.1 \%$ of respondents believe that the feminine/delicate and masculine/strong attributes are important for clothing brands to possess as this reflects who they are, whereas $31.2 \%$ of the respondents believe that it is unimportant for clothing brands to portray neither feminine nor masculine personality attributes, as this is not congruent with their actual self-concept. Hence, it can be inferred that the brand personality attribute which is of importance to clothing brand/s is feminine/delicate (female respondents) and masculine/strong (male respondents), as this is congruent with the respondents' actual self-concept. On the contrary, the least important brand personality attribute among the respondents is adventurous and outdoorsy personality, as this is incongruent with respondents' actual self-concept.

Ideal self-congruity: mobile phones - most/least important brand personality attributes: The results show that $37.7 \%$ of respondents believe that it is important for mobile phones to be innovative and up-todate, whereas $36.9 \%$ of respondents do not believe that it is important for mobile phones to possess this attribute. It can be assumed that the brand personality attribute that is of paramount importance among respondents is innovative and up-to-date. According to the results, $53.0 \%$ of respondents believe that it is not important for their mobile phone brand to be inexpensive as they would like to be extravagant or spendthrift consumers - this reflects their ideal self-concept. On the contrary, $16.9 \%$ of respondents believe that this attribute is important for mobile phones to possess as they would like to be thriftier and more financially cautious consumers. From the findings, it can be deduced that the brand personality attribute that is of importance to respondents is innovative and up-to-date, as this is congruent with how the respondents would like to be. On the contrary, the brand personality attribute that is of the least importance to respondents is inexpensive and thrifty, as this is incongruent with how the respondents would like to be.

Ideal self-congruity: clothing - most/least important brand personality attributes: The results indicate that $56.9 \%$ of respondents believe that the adventurous and outdoorsy attributes are not important for clothing brands to possess, while $16.1 \%$ of respondents believe that it is important for clothing brands to possess this attribute. This confirms that the majority of respondents do not perceive this attribute to be important when they elect to purchase clothing brands. From the research findings, $42.1 \%$ of respondents indicate the feminine and masculine brand personality attributes are important when they purchase clothing brands as this reflects how they would like to be, while $32.5 \%$ of respondents believe that it is unimportant for clothing brands to possess this attribute as this does not reflect how they would like to be. Ergo, the brand personality attribute that is of paramount importance to respondents is feminine (female respondents) and masculine (male respondents). On the contrary, the attribute that is of the least importance to respondents is adventurous and outdoorsy, as this is incongruent with how the respondents would like to be. From the results highlighted above, it can be assumed actual and ideal self-concepts are similar in nature as the brand personality traits which are of the most and least importance pertaining to the clothing and mobile brands that respondents purchase are the same. This notion is supported by the study conducted by Kleijnen, Ruyter \& Andreassen (2005), which revealed that actual and ideal self-concept are similar in nature and measuring 
the two concepts with brand personality attributes will be insignificant, as the measurement of the these variables is almost negligible.

The Impact of Actual and Ideal Self-congruity on Respondents' Biographical Variables: The biographical variables (age group, current year of study, gender, race, employment, living arrangements and income) on actual and ideal self-congruity and its impact on the respondents' purchase intentions were evaluated using tests of differences (Mann-Whitney U test and the Kruskal-Wallis ANOVA test. Table 2 depicts the results.

Hypothesis One: Respondents varying in (age group, current year of study, gender, race, employment, living arrangements and income) significantly differ in their perceptions of actual self-congruity and ideal selfcongruity and its influence on their purchase intentions.

Table 2: Kruskal-Wallis ANOVA Test: The Biographical Profiles of Respondents and the Influence of Actual and Ideal Self-congruity on Consumers' Purchase Intentions

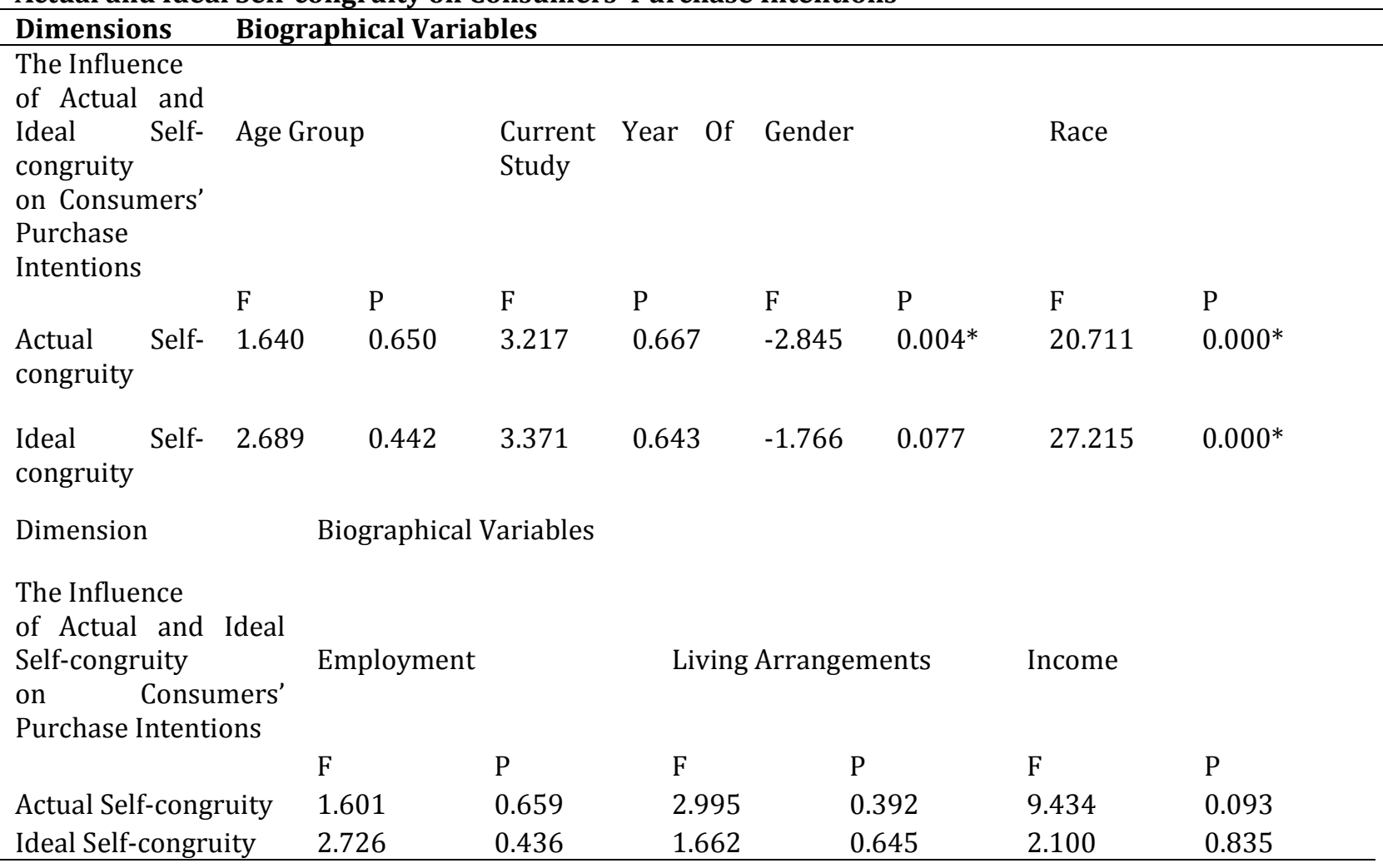

As evident in Table 2 the results depict that there is a significant difference in the perceptions of actual selfcongruity on gender $(Z=-2,845, p<0,05)$, however, there is no significant difference in the perceptions of ideal self-congruity $(Z=-1,766, p<0.05)$. Hence, hypothesis one may only be accepted in terms of actual selfcongruity. According to Table 2 the results show there is a significant difference in the actual self-congruity (Chi-Square $=20.711, \mathrm{df}=4, \mathrm{p}<0.01$ ) and ideal self-congruity for race (Chi-Square $=27.215, \mathrm{df}=4, \mathrm{p}<0.01$ ) of the respondents. Hence, hypothesis one can be accepted in terms of the respondents' race group for both actual and ideal self-congruity. Table 2 indicates that customers varying in biographical profiles (age, current year of study, employment, living arrangements and income) do not significantly differ in their perceptions of actual self-congruity and ideal self-congruity and its influence on their purchase intentions. Hence hypothesis 1 may be rejected.

Impact of Biographical Profiles of Respondents and its influence on purchase intentions: The biographical variables (age group, current year of study, gender, race, employment, living arrangements and 
income) on self-congruity and its impact on the respondents' purchase intentions were evaluated using tests of differences (Mann-Whitney U test and the Kruskal-Wallis ANOVA test) respectively.

Hypothesis Two: There is a significant difference in the perceptions of actual self-congruity and ideal selfcongruity between males and females on their purchase intentions.

Table 3: Mann-Whitney U Test: Sub-dimensions of Consumers' Purchase Intentions by Gender Sub-dimensions of Consumers' PurchaseMann-Whitney

\begin{tabular}{llll} 
Intentions & $\mathbf{U}$ & $\mathbf{Z}$ & $\mathbf{P}$ \\
\hline Actual self-congruity & 13914.000 & -2.845 & $0.004^{*}$ \\
Ideal Self-congruity & 15037.000 & -1.766 & 0.077
\end{tabular}

** $\mathrm{p}<0.05$

As evident in Table 3 the results show there is a significant difference in the perceptions of actual selfcongruity $(Z=-2,845, p<0,05)$, between males and females. Hence hypothesis 2 can be accepted.

Hypothesis Three: Respondents varying in (age group, current year of study, race, employment, living arrangements and income) significantly differ in their perceptions of actual self-congruity and ideal selfcongruity and its influence on their purchase intentions.

Table 4: Kruskal-Wallis ANOVA Test: Impact of Biographical Profiles of Respondents and its influence on purchase intentions

\begin{tabular}{|c|c|c|c|c|c|c|c|c|c|}
\hline \multirow{2}{*}{$\begin{array}{l}\text { Dimensions } \\
\text { The Influence } \\
\text { of Actual and Ideal } \\
\text { Self-congruity }\end{array}$} & \multicolumn{9}{|c|}{ Biographical Variables } \\
\hline & & & & & & & & & \\
\hline on Consumers' & \multicolumn{3}{|c|}{ Age group } & \multicolumn{3}{|c|}{ Current year of study } & \multicolumn{3}{|l|}{ Race } \\
\hline & $\begin{array}{l}\text { Chi- } \\
\text { Square }\end{array}$ & $\mathrm{df}$ & $\mathrm{P}$ & $\begin{array}{l}\text { Chi- } \\
\text { Square }\end{array}$ & $\mathrm{df}$ & $\mathrm{P}$ & $\begin{array}{l}\text { Chi- } \\
\text { Square }\end{array}$ & $\mathrm{df}$ & $\mathrm{P}$ \\
\hline $\begin{array}{l}\text { Actual } \\
\text { congruity }\end{array}$ & 1.640 & 3 & 0.650 & 3.217 & 5 & 0.667 & 20.711 & 4 & $0.000^{*}$ \\
\hline Ideal Self-congruity & 2.689 & 3 & 0.442 & 3.371 & 5 & 0.643 & 27.215 & 4 & $0.000 *$ \\
\hline $\begin{array}{l}\text { Dimensions } \\
\text { The Influence } \\
\text { of Actual and Ideal } \\
\text { Self-congruity }\end{array}$ & \multicolumn{9}{|c|}{ Biographical Variables } \\
\hline on Consumers' & \multicolumn{3}{|c|}{ Employment } & \multicolumn{3}{|c|}{ Living arrangements } & \multicolumn{3}{|l|}{ Income } \\
\hline & $\begin{array}{l}\text { Chi- } \\
\text { Square }\end{array}$ & $\mathrm{df}$ & $\mathrm{P}$ & $\begin{array}{l}\text { Chi- } \\
\text { Square }\end{array}$ & $\mathrm{df}$ & $\mathrm{P}$ & $\begin{array}{l}\text { Chi- } \\
\text { Square }\end{array}$ & $\mathrm{df}$ & $P$ \\
\hline $\begin{array}{l}\text { Actual } \\
\text { congruity }\end{array}$ & 1.601 & 3 & 0.659 & 2.995 & 3 & 0.392 & 9.434 & 5 & 0.093 \\
\hline Ideal Self-congruity & 2.726 & 3 & 0.436 & 1.662 & 3 & 0.645 & 2.100 & 5 & 0.835 \\
\hline
\end{tabular}

Table 4 indicates that there is a significant difference in the actual self-congruity (Chi-Square $=20.711, \mathrm{df}=4$, $\mathrm{p}<0.01$ ) and ideal self-congruity for race (Chi-Square $=27.215, \mathrm{df}=4, \mathrm{p}<0.01$ ) of the respondents. Hence, 
hypothesis three can be accepted in terms of the respondents' race group for both actual and ideal selfcongruity. In addition, table 4 indicates that respondents varying in (age group, current year of study, employment, living arrangements and income) do not significantly differ in their perceptions of actual selfcongruity and ideal self-congruity and its influence on their purchase intentions. Therefore hypothesis three is rejected in terms of these dimensions.

Discussion of Results: In terms of respondents' perceptions of the dimension of actual self-congruity pertaining to purchase intentions, the empirical findings demonstrate that respondents purchase clothing and mobile phone brands with attributes that are congruent with their actual self-concept. In addition, the results show that the majority of respondents care about the types of clothing and mobile phone brands that are purchased as it reflects who they are. Conversely, a small segment of respondents indicate that they do not care about the types of clothing and mobile phone brands that are purchased as it does not reflect who they are. It can be assumed that these respondents do not have a firm sense of self identity nor were they able to distinguish between actual and ideal self-concept. As evident in the results, the majority of respondents purchase brands which are influenced more by their actual rather than their ideal self-concept. This finding is inconsistent with the studies conducted by Ekinci, Dawes \& Massey (2008); Graeff (1996) and Hong \& Zinkhan (1995), where they declare that consumers' purchase intentions are driven more by their ideal selfconcept rather than their actual self-concept. The plethora of studies indicate that consumers purchase brands that match their actual self-concept as brands are vehicles for expressing who they are - this is portrayed in the results. Pioneer studies conducted by Sirgy in 1982 and Belk in 1988, support the findings of the research as well, where they stated that the self-congruity theory involves consumers evaluating brands on the basis of the various dimensions by which consumers describe themselves (as cited in Parker, 2005).

In terms of respondents' perceptions of dimension of ideal self-congruity pertaining to purchase intentions, the results indicate that respondents purchase clothing and mobile phone brands with attributes that are congruent with their ideal self-concept as well. Sirgy and Su (2000) support this notion as they postulate that consumers purchase brands that possess images that are congruent with both their actual and ideal selfconcept. The results also illustrate that a considerable percentage of respondents care about the type of clothing and mobile phone brands that are purchased as it reflects how they would like to be. A study conducted by Hong \& Zinkhan (1995) revealed that consumers are influenced more by their ideal selfconcept rather their actual self-concept when it comes to purchasing other conspicuous products, namely cars and shampoos. The findings thus indicate that respondents purchase clothing and mobile phone brands that are congruent with both their actual and ideal self-concepts. Ericksen (1997) and Choi \& Rifon (2012) declare that self-congruity positively affects consumers' purchase intentions; this reveals that when there is a positive relationship or a match between consumer's self-concept and brand image, this influences consumers' purchase intentions positively.

However, there is a slight variation in the responses, which indicate that respondents purchase clothing and mobile phones that express who they are rather than how they would like to be. The results also depict that there is no significant difference between the respondents' actual and ideal self-congruity on purchase intentions. Kleijnen et al. (2005) support this finding and postulate that actual and ideal self-concept are similar in nature, ergo, measuring actual and ideal self-congruence with brand personality attributes is insignificant as the measurement of the these variables is almost negligible. Additionally, Webb \& Gountas (2006) posit that there is no clear evidence of whether actual and ideal self-image is related to actual and ideal product image. In consumer behaviour research, the congruity of self-concept and brand personality attributes illuminates and enhances the understanding of consumer decision-making, ergo, the crux of this study was to unearth whether consumers purchase clothing and mobile phone brands with attributes that are congruent with their actual and ideal self-concepts. From the results, it can be deduced that respondents purchase brands that are congruent with both their actual and ideal self-concepts, however, upon closer reflection, it can be professed that respondents' purchase intentions are influenced slightly more by their actual rather than their ideal self-congruity.

The following segment will illuminate the brand personality attributes that are of the most and least importance to the respondents, with reference to their actual and ideal self-concepts, when purchasing clothing and mobile phones. The researcher utilized a specific set of brand personality attributes that are of 
great relevance to the student community which were selected by taking into consideration the several Brand Personality scales by Aaker (1997), Grohmann (2009), Malhotra (1981) and Geuens et al. (2009). According to Belk, (1988); Sirgy, (1982) and Solomon, (1983), consumers prefer brands and stores that project images that are congruent with or similar to how they perceive themselves (as cited in Parker, 2005). Graeff (1996) also supports this notion. Park \& Lee (2005); Sirgy \& Johar (1999); Sirgy \& Su (2000) and Sung, Park \& Han (2005) have explored the effects of the congruence between brand personality attributes and the self-concept of consumers and according to Belk, 1988 and Sirgy, 1982 (as cited in Achouri \& Bouslama, 2010), an individual seeks certain congruence between the attributes of a brand and the way his/her personality is presented.

Ericksen (1997) postulates that there is a significant relationship between consumers' self-congruity and purchase intention and as indicated in the results, the respondents elect to purchase brands with personality attributes that are in fact congruent with their actual and ideal self-concepts. Furthermore, Ericksen (1997); Jamal \& Goode (2001) and Zinkhan \& Hong (1991) have pointed out that consumers prefer brands with images or attributes that are compatible with their own self-perceptions or self-concepts. Ergo, from the results, it can be extrapolated that, with reference to the respondents' actual self-concept, pertinent to mobile phones, the brand personality attribute that is of paramount importance among respondents is the innovative and up-to-date attribute. The results dictate that respondents will elect to purchase a mobile phone that is innovative and up-to-date as this is congruent with their actual self-concept or how they currently view themselves. Furthermore, the brand personality attribute that is of the least importance to the respondents vis-à-vis mobile phones is the inexpensive and thrifty characteristic. This confirms that the respondents of this study do not perceive themselves as frugal consumers. However, a study conducted by Student Village in 2013 confirmed that 70\% of students are saving between R0-R250 in order to save for 'emergencies' (Student Village, 2013). In addition, the South African Student Spend Report 2015 revealed that $58 \%$ of students are now saving between R1-R540 for 'rainy days' (Student Village, 2015). As indicated by the statistics in the two studies conducted by Student Village above, it is evident that student saving has declined in the last two years (Student Village, 2013; 2015). This is reflected in the results of the current study at hand, whereby respondents do not perceive themselves as thrifty consumers. Consequently, it can be declared that inexpensive and thrifty reflect attributes that are inconsistent with how the respondents perceive themselves when they purchase brands of mobile phones.

With reference to the respondents' ideal self-concept, vis-à-vis mobile phones, the brand personality attribute that is of importance to the respondents is the innovative and up-to-date attribute, which confirms that respondents consider this attribute important when they elect to purchase a mobile phone as it is congruent with their ideal self-concept. Furthermore, the brand personality attribute that is of the least importance to respondents is the inexpensive and thrifty characteristic as this attribute does not reflect how the respondents would like to be. The findings thus indicate that the majority of respondents are concerned about purchasing expensive mobile phone brands and being thrifty is unimportant and as shown in the studies conducted by Student Village in 2013 and 2015, student saving has now declined in the last two years (Student Village, 2013; 2015). This is reflected in the results of the current study, where respondents do not perceive themselves as thrifty consumers. Furthermore, the results depict that there is a significant difference in the perceptions of actual and ideal self-congruity among the race groups of the respondents. This finding is evident in the study conducted by Student Village in 2013, where it was revealed that students from diverse ethnic backgrounds spend and consume differently. The study indicated that White students spend their money on food, groceries, holiday travel, entertainment and alcohol, African students spend their money on toiletries, cosmetics, take-away meals, gadgets, extra tuition and music and Coloured students spend their money on smoking, bling, magazines, clothing and footwear (Student Village, 2013). It can be deduced that students from different ethnicities prefer, are loyal towards and satisfied with a variety of different brands and their consumption behaviour varies. The study, however, did not reveal findings pertaining to the Indian student community.

The findings depict that the majority of the respondents earned a minimal income of less than R1 000. This correlates with the findings from the study conducted by Kornberger et al. (2010), where it was revealed that students living with their parents have less disposable income compared to those who are renting or living on their own. Ergo, it can be assumed that the discretionary income of the respondents in this study is meagre 
which does not give them the financial freedom to purchase highly expensive brands. However, according to the South African Student Spend Report 2015, where 3030 respondents from various tertiary institutions across South Africa were surveyed, it was revealed that the average student spending across South Africa in 2015 is R2 702 per month, which has increased by 7.95\% since 2014. It is important to note that this average student spend is much higher than the disposable income of the respondents in this study, as most respondents from this study have a discretionary income of less than R1 000. According to a study conducted in 2013, by Student Village, on South African student spending, it was revealed that females are spending more of their income than their male counterparts (Student Village, 2013). However, in 2015, the South African Student Spend Report 2015, conducted by Student Village revealed that males spend more than females (Student Village, 2015).

Moreover, there is no significant difference in the perceptions of actual and ideal self-congruity among the income levels of the respondents. According to the South African Student Spending Report 2013 and 2015, students' main source of income comes from their parents or other family members, and the other sources of income include part-time work and bursaries or sponsors (Student Village, 2013; 2015). It was also revealed by Student Village, that students are still spending more than the average South African citizen per annum in spite of the fact that students are stereotyped as being broke or virtually penniless (Student Village, 2013; 2015). However, this is not true for the respondents in this study as most of them can be perceived to be financially disadvantaged.

\section{Conclusion and Recommendations}

This research is of particular relevance to marketing managers, as they need to be aware of their target consumers' actual and ideal self-congruity and how these elements impact on consumers' purchase intentions. These elements, as evident in the empirical findings, in turn, influence consumers' brand loyalty, brand preference and customer-brand satisfaction, which ultimately affect product sales. A surfeit of studies has hypothesized self-concept and brand personality and has revealed that these elements significantly influence consumers' brand preference, brand loyalty and customer-brand satisfaction as indicated in the results of this study. Although the empirical findings indicate that both actual and ideal self-congruity influence purchase intentions, it was discovered that students purchase brands that are influenced slightly more by their actual rather than their ideal self-concept. Ergo, it is imperative that marketing managers determine students' ideal self-concept by engaging in continuous marketing research in order to determine what motivates students to purchase a particular brand and what brand personality attributes will enhance students' self-concept. By conducting continuous market research, firms will be able to customize their offerings according to students' predilections. Firms are also required to utilize more aggressive advertising appeals and strategies in order to illustrate and communicate to students how their brands can bring students closer to their ideal self-concept. Furthermore, it is recommended that firms continuously communicate with the student market segment via personalized, interactive forms of communication in order to operate successfully in today's constantly evolving digital marketing landscape.

Since the findings indicate that students regard the innovative and up-to-date attributes as the most important attribute pertaining to mobile phones and the feminine and masculine attributes as the most important regarding clothing brands as these attributes reflect their actual self-concept, marketing managers are required to take these brand personality attributes into consideration when they are devising their marketing strategies. Ergo, in order to effectively penetrate and target this market segment, marketing managers need to customize their offerings and marketing communications in accordance with students being innovative and up-to-date and feminine and masculine. The feminine and masculine brand personality attributes can also be streamlined or customized for various product categories other than for clothing, namely health and fitness products, toiletries, hotels, insurance services and even jewelry. The innovative and up-to-date brand personality attributes can be utilized for product categories other than for mobile phones, namely watches, motor vehicles and major household durables. The findings also indicate that most students are not frugal consumers as this attribute does not reflect their actual self-concept, ergo marketing managers can capitalize on this attribute, as it is evident that students are not price sensitive consumers. The adventurous and outdoorsy attributes are off little or no relevance to students pertaining to clothing brands, 
as this is not incongruent with students' actual self-concept; therefore, marketing managers need to refrain from using these attributes in their marketing activities when targeting students' actual self-concept.

The most important attributes pertaining to mobile phones and clothing that are congruent with reference to students' ideal self-concept are the same as the attributes that are congruent with students' actual selfconcept. Ergo, marketing managers are required to take these attributes into consideration when they are devising their marketing strategies for such products that will appeal to students' ideal self-concept. The attributes that are the least important pertaining to mobile phones and clothing with respect to students' ideal self-concept are the same as those attributes that are congruent with students' actual self-concept. The highest value of students' purchase is premium clothing, followed by mobile phones (Student Village, 2015). Ergo, this study focused on students' actual and ideal self-congruity pertaining to the clothing and mobile phone brands they purchase. Hence, from the findings, it is recommended that firms incorporate both the actual and ideal self-concepts into their marketing and advertising activities for mobile phone and clothing in order to effectively compete in today's dynamic market landscape and successfully target the student market segment. The cardinal point of this study was to ascertain whether consumers purchase (clothing and mobile phones) brands with personality attributes that are congruent with their actual and ideal self-concepts. The empirical findings thus indicate that actual and ideal self-congruity does in fact influence the purchase intentions of consumers. The research also indicates that there exists an influential and significant relationship among the dimensions that were under investigation. Moreover, it can be inferred that consumers' actual self-congruity has a greater influence over ideal self-congruity on consumers' purchase intentions. Hence, taking the aforementioned into consideration, the purpose of this research has been fulfilled.

Recommendations for Future Research: This research has been confined to within a Public Tertiary Institution in EThekwini (Durban), South Africa and was conducted comprising of postgraduate and undergraduate students from three colleges only. The institution comprised of thirteen Schools. Further research on this subject should be expanded to other tertiary institutions and could employ larger sample sizes and a more diverse sample unit comprising of respondents from campuses located nation-wide. Furthermore, an extensive assortment of other product consortiums should be employed in order to obtain further insight into consumers' actual and ideal self-congruity and their influence on purchase decisions. Future research should incorporate the usage of brand names as this was not utilized in the study and consequently the study was more generalized in nature. Moreover, apart from the actual and ideal selfconcepts, the social and ideal social selves should also be taken into consideration in order to yield a more panoptic study.

\section{References}

Aaker, J. L. (1997). Dimensions of Brand Personality. Journal of Marketing Research, 34(3), 347-356.

Aaker, J. L. (1999). The Malleable Self: The Role of Self-expression in Persuasion. Journal of Marketing Research Available at: https://www.gsb.stanford.edu/sites/gsb/files/publication-pdf/TheMalleable-Self.pdf.

Abel, J. I. \& Buff, C. L. (2010). Exploring Gender Differences under the Image Congruence Hypothesis among Consumers in the Health Club Industry. Journal of the Academy of Business and Economics, 10(3).

Achouri, M. L. \& Bouslama, N. (2010). The Effect of the Congruence between Brand Personality and Self-Image on Consumer's Satisfaction and Loyalty: A Conceptual Framework. IBIMA Business Review Available at: www.ibimapublishing.com/journals/IBIMABR/2010/627203/627203.pdf.

Belk, R.W. (1988). Possessions and the Extended Self. Journal of Consumer Research, 15(2), 139-168.

Boksberger, P., Dolnicar, S., Laesser, C. \& Randle, M. (2011). Self-Congruity Theory: To What Extent Does it Hold in Tourism? Journal of Travel Research, 50(4), 454-456. Available at: http://ro.uow.edu.au/cgi /viewcontent.cgi? article $=2011 \&$ context $=$ commpapers.

Choi, S. M. \& Rifon, N. J. (2012). It is a Match: The Impact of Congruence Between Celebrity Image and Consumer Ideal Self on Endorsement Effectiveness. Psychology \& Marketing, 29(9), 639-650.

Conger, D. \& Long, M. C. (2013). Women Students Dominating in Many Countries. Available at: http://www.universityworldnews.com/article.php?story= 2013022612105131. 
Eder, J. (2013). Are Students Becoming More Brand Loyal? Available at: http://www.theguardian.com/medianetwork/media-network-blog/2013/aug/16/ students-youth-brand-entertainment-loyalty.

Eder, J. (2013). How Brands Can Build and Sustain Relationships With 18-to-24-year-olds. Available at: http://www.marketingmagazine.co.uk/article/1207773/bra nds-build-sustain-relationships-18-24year-olds.

Ekinci, Y. \& Riley, M. (2003). An Investigation of Self-concept: Actual and Ideal Self-congruence Compared in the Context of Service Evaluation. Journal of Retailing and Customer Service, 10(4), 201-214.

Ekinci, Y., Dawes, P. L. \& Massey, G. R. (2008). An Extended Model of the Antecedents and Consequences of Consumer Satisfaction for Hospitality Services. Journal of Euro-Marketing, 42(1/2), 35-68.

Ericksen, M. K. (1996). Using Self-Congruity and Ideal Congruity to Predict Purchase Intention: A European Perspective. Journal of Euro-Marketing, 6(1), 41-56.

Ericksen, M. K. (1997). Using Self-congruity and Ideal Congruity to Predict Purchase Intention: A European Perspective. Journal of Euro-Marketing, 6(1), 41-56.

Escalas, J. E. \& Bettman, J. R. (2005). Self-construal, Reference Groups and Brand Meaning. Journal of Consumer Research, 32(3), 378-389.

Grant, I. C. \& Waite, K. (2003). Following the Yellow Brick Road - Young Adults' Experiences of the Information Super-Highway. Qualitative Market Research: An International Journal, 6(1), 48-57.

Geuens, M., Weijters, B. \& De Wulf, K. (2009). A New Measure of Brand Personality. International Journal of Research in Marketing, 26(2), 97-107.

Graeff, T. R. (1996). Image Congruence Effects on Product Evaluations: The Role of Self-monitoring and Public/Private Consumption. Journal of Psychology \& Marketing, 13(5), 481-499.

Grohmann, B. (2009). Gender Dimensions of Brand Personality. Journal of Marketing Research, 46(1), 105119.

Han, J. W. (2006). The Impact of Self-Concept/Product-Image Congruity and Functional Congruity on Brand Preference: Three Product Categories. Available at: http://diginole.lib.fsu.edu/cgi/viewcontent.cgi?article=1682\&context =etd.

Hong, J. W. \& Zinkhan, G. M. (1995). Self-concept and Advertising Effectiveness: The Influence of Congruency, Conspicuousness, and Response Mode. Psychology \& Marketing, 12(1), 53-77.

Hogg, M. K., Bruce, M. \& Hill, A. J. (1998). Fashion Brand Preference among Young Consumers. International Journal of Retail and Distribution Management, 26(8), 293-300.

Jamal, A. \& Goode, M. H. (2001). Consumer and Brands: A Study of the Impact of Self-image Congruence on Brand Preference and Satisfaction. Marketing Intelligence \& Planning, 19(7), 482-492.

Johar, G. V., Sengupta, J. \& Aaker, J. L. (2005). Two Roads to Updating Brand Personality Impressions: Trait versus Evaluative Inferencing. Journal of Marketing Research, 42(4), 458-469.

Keller, K. L. \& Richey, K. (2006). The Importance of Corporate Brand Personality Traits to a Successful 21st Century Business. Journal of Brand Management, 14(1/2), 74-81.

Kim, C. K., Han, D. \& Park, S. (2001). The Effect of Brand Personality and Brand Identification on Brand Loyalty: Applying the Theory of Social Identification. Japanese Psychological Research, 43(4), 195206.

Kim, H. R., Lee, M. \& Ulgado, F. M. (2005). Brand Personality, Self-congruity and the Consumer-brand Relationship. AP - Asia Pacific Advances in Consumer Research 6, 111-117. Available at: http://acrwebsite.org/volumes/11876 /volumes/ ap06/AP-06.

Kleijnen, M., Ruyter, K. \& Andreassen, T. (2005). Image Congruence and the Adoption of Service Innovations. Journal of Service Research, 7(4), 343-359.

Kornberger, M., Aires, R., Cant, M. \& Bothma, N. (2010). 15 Things You Didn't Know About Student Spending Behaviour. Available at: http://www. slideshare.net/jniemand/student-marketing-studentspending-behavior-south-africa-2010.

Kotler, P. (2000). Marketing Management: Millennium Edition (Tenth Edition), Prentice-Hall.

Leslie, E., Sparling, P. B. \& Owen, N. (2001). University Campus Setting and the Promotion of Physical Activity in Young Adults: Lessons from Research in Australia and the USA. Health and Education, 101(3), 116125.

Malhotra, N. K. (1981). A Scale to Measure Self-concepts, Person Concepts, and Product Concepts. Journal of Marketing Research 18(4), 456-464. Available at: https://archive.ama.org/archive/ResourceLibrary/JournalofMarketing Research (JMR)/documents/5018947.pdf. 
Mehta, A. (1999). Using Self-concept to Assess Advertising Effectiveness. Journal of Advertising Research, 39(1), 81-89.

Mokhlis, S. \& Salleh, H. (2009). Consumer Decision-making Styles in Malaysia: An Exploratory Study of Gender Differences. European Journal of Social Sciences, 10(4), 574.

Parker, B. T. (2005). This Brand's For Me: Brand Personality and User Imagery Based Self-congruity. PhD Thesis. University of Florida. Available at: http://etd.fcla .edu/UF/UFE0012900/parker_b.pdf.

Park, S. Y. \& Lee, E. M. (2005). Congruence between Brand Personality and Self-image and the Mediating Roles of Satisfaction and Consumer-brand Relationship on Brand Loyalty. AP-Asia Pacific Advances in Consumer Research 6, 39-45. Available at: http://acrwebsite.org/volumes/11859/ vol/ap06/ AP-06.

Randle, M. J. \& Dolnicar, S. (2009). Self-congruity Theory in Volunteering. 38th EMAC Conference, France, 2629 May 2009, France: Audencia Group, 1-8. Available at: http://ro.uow.edu.au/cgi/viewcontent.cgi?article $=1651 \&$ cont ext=commpapers.

Schiffman, L. G. \& Kanuk, L. L. (2000). Consumer Behaviour (Seventh Edition), Englewood Cliffs, N.J.: PrenticeHall.

Sekaran, U. (2003). Research Methods for Business: A Skill-building Approach (Fourth Edition), London: John Wiley \& Sons.

Sirgy, M. J. (1982). Self-Concept in Consumer Behavior: A Critical Review. Journal of Consumer Research, 9(2), 287-300.

Sirgy, M. J. \& Johar, J. S. (1999). Toward an Integrated Model of Self-congruity and Functional Congruity. $E$ European Advances in Consumer Research 4, 252-256. Available at: http://acrwebsite.org/volumes/11391/ volumes/e04/E-04.

Sirgy, M. J. \& Su, C. (2000). Destination Image, Self-congruity, and Travel Behavior: Toward an Integrative Model. Journal of Travel Research, 38(4), 340-352.

Sirgy, M. J., Lee, D. J., Johar, J. S. \& Tidwell, J. (2008). Effect of Self-congruity with Sponsorship on Brand Loyalty. Journal of Business Research, 61(10), 1091-1097.

Smith, S. (2013). Determining Sample Size: How to Ensure You Get the Correct Sample Size. Available at: http://www.qualtrics.com/blog/determining-sample-size.

Sohn, E. M. \& Juan, J. (2011). Tourist Self-concept, Self-congruity, and Travel Behavior Based on Cultural Event. Available at: http://scholarworks .umass.edu/cgi/viewcontent.cgi?article=1136\&context=gradconf_hospitality.

Statistics South Africa. (2014). Mid-year Population Estimates 2014. Available at: http://www.statssa.gov.za/publications/P0302/P03022014.pdf.

Student Village. (2013). SA Student Spending Report 2013 Findings. Available at: http://www.studentmarketing.co.za/sa-student-spending-report-2013-findings.

Student Village. (2015). Student Spend Report 2015. Available at: http://www.stu dentmarketing.co.za/portfolio/student-spend-report-2015.

Sung, Y. S., Park, E. \& Han, M. K. (2005). The Influences of the Brand Personality on Brand Attachment and Brand Loyalty: Centred on the Differences Between the Brand Community Members and Nonmembers. AP - Asia Pacific Advances in Consumer Research 6, 156. Available at: http:// acrwebsite.org/volumes/11888/volumes/ap06/AP-06.

Van De Rijdt, T. (2008). Measuring Self-congruity Using Human Personality and Brand Personality: The Effect of Personality Congruence on Brand Preference. Available at: http://essay.utwente.nl/57756/1/scriptie_van_de_Rijdt.pdf.

Webb, B. \& Gountas, J. (2006). An Integrative Model of Brand Personality, Self-concept and Consumer Personality Orientations. ANZMAC 2006 Advancing Theory, Maintaining Relevance, Brisbane, 4-6 December 2006, Brisbane, Qld: Queensland University of Technology, School of Advertising, Marketing and Public Relations, 1-7. Available at: http://anzmac.org/conference archive/2006/documents/Webb_Ben.pdf.

Yutar, D. (2005). South African Youth Are Big Spenders. Available at: http://www.iol .co.za/news/southafrica/south-african-youth-are-big-spenders-1.244459\#.Veg_Ly Wqqko.

Zinkhan, G. M., Haytko, D. L. \& Ward, A. (1996). Self-concept Theory: Applications in Advertising Journal of Marketing Communications, 2(1), 1-19.

Zinkhan, G. M. \& Hong, J. W. (1991). Self-concept and Advertising Effectiveness: A Conceptual Model of Congruency, Conspicuousness, and Response Mode. Advances in Consumer Research 18, 348-354. Available at: http://www.a crwebsite.org/search/view-conference-proceedings.aspx ?Id=7184. 